
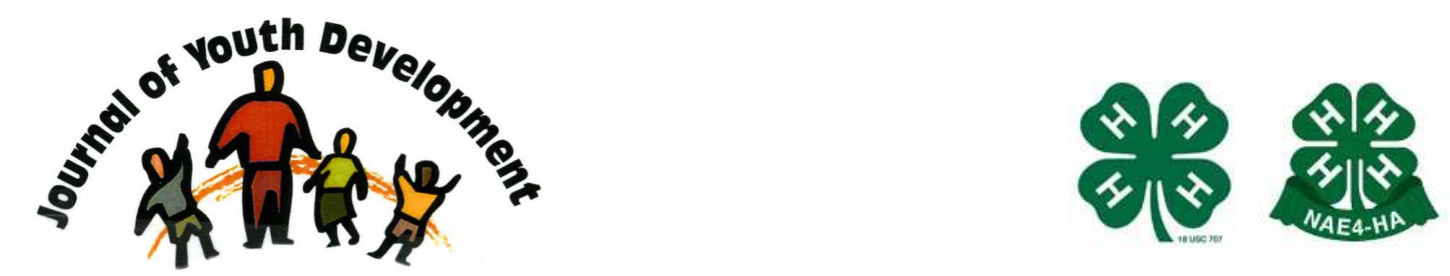

Bridging Research \& Practice

\title{
Assessing Service-Learning in a College-Level Adolescent Development Course
}

\author{
Cheryl L. Lee
}

Appalachian State University

Boone, NC

leecl@appstate.edu 


\title{
JOURNAL OF YOUTH DEVELOPMENT \\ bridging research and practice

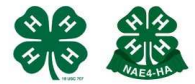

Volume 4, Number 2, Summer 2009

Article 090402PA003

\section{Assessing Service-Learning in a College-Level Adolescent Development Course}

\author{
Cheryl L. Lee \\ Appalachian State University
}

\begin{abstract}
Service-learning is an instructional method in which students learn course content by actively participating in thoughtfully organized service experiences related to the content. Effectively linking servicelearning to course content not only offers students a powerful opportunity to maximize academic learning, but also promotes their personal growth and instills a commitment to lifelong, civic engagement.
\end{abstract}

Service-learning was integrated into an upper level Family and Consumer Sciences Adolescent Development course. In addition to completing the traditional course work, students also completed a service-learning experience at a community agency that served adolescents. In order to evaluate the effectiveness of the servicelearning component, students were surveyed at the end of the semester about their service-learning experiences. All agreed they had learned more about course concepts as a result of their SL experience, and the majority felt their service-learning activity provided a needed service to the agency and community.

\section{Introduction}

Educators have increasingly embraced opportunities to prepare college students for future leadership roles by integrating service-learning into their courses (Ash, 2003; Batchelder \& Root, 1994; Boss, 1995; MacDonald, 1994; Smith, 2002; Truesdell, 2001). Service-learning is an instructional method in which students learn course content by actively participating in thoughtfully organized service experiences related to that content.

Service-learning is distinguished from other approaches to experiential education by its intent to benefit both the provider and recipient of the service, giving equal focus to the service being provided and the learning that is occurring (Furco, 1996). The service must be linked to course learning objectives; it is not simply volunteering. Experiences that enable students to think, 
write, and/or discuss what they are doing during the service activity are integrated into the course. Effectively linking service-learning to course content not only offers students a powerful opportunity to maximize academic learning, but also promotes their personal growth and instills a commitment to lifelong, civic engagement.

Service-learning does, of course, involve challenges. Depending on the course and its content, educators may need to invest considerable time in locating appropriate service learning sites and preparing effective service activities. The reflective experiences which are necessary to help students make connections between course content and their service-learning require time and may mean a reduction in the amount of class time available for content coverage. In addition, educators may occasionally need to assume the role of mediator between students and their service-learning sites if miscommunication occurs.

At Appalachian State University, service-learning was integrated into an upper level undergraduate course, Adolescent Development, to enable students to connect research and theory with active practice. The purpose of this study was to evaluate the service-learning component of the course.

\section{Methodology}

In the original Adolescent Development course, students examined the basic changes, contexts, and developmental tasks of adolescence. The course outline indicating the content is provided below:

- Basic changes of adolescence

- Biological transitions

- Cognitive transitions

- Social transitions

- Contexts of adolescence

- Families

- Peer groups

- Schools

- Psychosocial development during adolescence

- Identity

- Autonomy

- Intimacy

- Sexuality

- Achievement

- Psychosocial problems in adolescence

- Substance abuse

- Externalizing problems

- Internalizing problems

While the content in the original Adolescent Development course was certainly appropriate, the course seemed to provide primarily facts and information about the stage of life called "adolescence." The class did not seem to connect the students with the various challenges experienced by adolescents. Therefore, while the content remained the same, the class was revised to incorporate a service-learning project that would enable students to observe and apply course concepts through association with adolescents. The service-learning project 
required students to work with adolescents for two hours per week for nine weeks of the semester. Students completed their service-learning by working at community agencies that served adolescents, such as after-school programs and residential treatment centers.

Students completed their service-learning at a variety of community agencies, from programs that served typical adolescents to centers for at-risk youth. Students chose from the following agencies:

- Watauga Youth Network, a big brother/sister program for adjudicated youth

- Watauga Youth Network Resource Center, an after-school program for adjudicated youth

- GEAR UP, an after-school program for high school students planning to attend college

- Upward Bound, a program assisting first-generation beginning college students from low-income families

- Mountain Alliance, an outdoor experiential program for at-risk youth

- Watauga County after-school programs

- Cherokee Park Youth Center, a residential treatment program for adjudicated adolescents

Depending on the site, students engaged in a variety of experiences with the respective agency adolescents including: tutoring, sports activities, arts and crafts, hiking canoeing, caving, and just "hanging out." Although students were often engaged in group activities, they selected one adolescent upon which to focus their observations and reflections and generally had ample one-on-one time with that adolescent.

Throughout the semester, students engaged in several class activities that enabled them to reflect upon their service-learning and connect it to course content. For example, as the concept of identity development was addressed, students not only read about and discussed it, but also assessed the identity development of the adolescent upon whom they were focusing. In the study of internalizing problems, students not only researched the latest adolescent suicide statistics, but they also reflected upon any warning signals their adolescent might be exhibiting.

In addition to the class activities, students prepared a report in which they applied the concepts they were learning in class to their particular adolescent. They used the theories and research to explain their adolescent's development and behavior. For example, students utilized Piaget's theory of cognitive development to assess adolescents' stages of cognitive development and referred to Erikson's eight stages of development to explain adolescents' identify development. Students researched characteristics of juvenile offenders and compared to their adolescents' particular characteristics and risky behaviors.

\section{Evaluation}

At the end of the semester, all 24 students completed a survey that evaluated the servicelearning component of the course. Respondents represented the following majors: child development, family and consumer sciences education, sociology, and psychology. Thirteen were seniors, nine were juniors, and two were freshmen. 
The majority of students felt that the academic projects associated with their service-learning experience helped them to more effectively learn and retain the course material. On a 4-point scale, with 4 being "strongly agree," the average response was 3.5. Their level of satisfaction seemed particularly significant considering the additional time commitment outside of class associated with the service-learning. Other findings included the following:

- $84 \%$ of the students agreed that they had been adequately prepared for their servicelearning experience

- $\quad 96 \%$ agreed that the service-learning made the course more interesting and applicable to "real world" issues

- $80 \%$ agreed that their time was effectively used while serving at their agency

- $88 \%$ agreed that the class had helped them to become more aware of social issues that existed in the community

- $\quad 88 \%$ felt their service-learning activity provided a needed service to the agency and community all agreed they had learned more about the concepts presented in the course as a result of their service-learning experience.

- All agreed they had learned more about the concepts presented in the course as a result of their service-learning experience

Almost every student agreed that the service-learning experience made the course more interesting and applicable to the "real world." One student noted, "It is different to see things rather than just read about them in a textbook. It was interesting to get to see how the adolescent I was observing exemplified the concepts we were learning in class." Others noted the value of gaining experiences related to their futures: "I am a prospective teacher, and the service-learning put me in that role" and "Observing at-risk adolescents helped me to see who I will be working with in the future."

Several students noted the personal growth they experienced through the service-learning.

- "I felt like I made a difference to the girls with whom I worked."

- "I got to take a look at what it was like to be a teenager again. Adolescents are just trying to find out who they are, and a lot of people forget about that."

- "I found that I could learn as much from the adolescents as they could from me!"

The service-learning helped many students become more aware of social issues that existed in the community. As one student said, "I never realized that there were so many adolescents who came from bad homes or who had gotten into trouble and needed someone to help them out. My service-learning experience showed me that there are people out there who need help and I can make a difference by being involved." Another stated, "More kids drink and do drugs than I thought."

This service-learning experience seemed to give many students their first meaningful experience with diversity and helped them to question some previous assumptions and stereotypes they had held.

- $\quad$ "The service-learning experience caused me to look at adolescents differently than I had before and also to understand better that a person's lifestyle does not always dictate the person that they are inside."

- "I believe that it made me more empathic to other people's situations." 
- "I became more accepting towards others and realized that they aren't much different from me, other than they might not have been given the opportunities I have."

In a final open-ended question, students were asked to share the most important thing they had learned during their service-learning experience. Responses including the following:

- "How adolescents think and work"

- "That I love getting to know all kinds and ages of people"

- "That I do enjoy service"

- "How blessed I am to have the family situation and opportunities that I do"

- "You can't learn everything from a textbook; it can't prepare you for the real experiences"

- "That all adolescents have their own unique personalities"

- "That not everyone had a good life like me"

- "Positive interactions can greatly influence adolescents in the right direction"

- "Adolescents are unique and interesting individuals who deserve respect and a chance to express who they are"

No formal evaluations were completed by service-learning site supervisors; however, several commented on the success and helpfulness of the project. One site supervisor shared, "The service-learning enabled our agency to better carry out its mission of helping young people."

\section{Implications and Future Plans}

In this Adolescent Development class, the service-learning project enabled students to apply course concepts in the real world and then bring the lessons they learned back to the classroom; this experience enriched the learning environment for all. Therefore, the servicelearning component will continue to be a part of this class. Efforts will be made to secure additional sites to provide further diversity for future service-learning experiences. Further reflection activities will also be developed to provide even more opportunities for students to connect the course concepts with their service-learning.

In addition, the university's service-learning office is developing more assessment strategies to better evaluate all service-learning courses across the campus. Increased emphasis is being given to faculty development in the form of workshops and actual service experiences. Most recently, the university has implemented a Designated Service-Learning Faculty Program to recognize and reward faculty for their dedication to improving their teaching effectiveness related to service-learning, as well as engaging in scholarship and service in this area. It appears that both educators and administrators are recognizing the value of service-learning as an instructional method.

Other programs and classes might also utilize service-learning to enable students to better understand course concepts, as well as broaden their perspectives. There are numerous opportunities in all communities to "give back" by allowing student to apply what they are learning in class. For example, students in nutrition or food service programs could provide menu-planning or food preparation services for homeless shelters or organize a food drive for a food bank. Child development majors might serve at the local "Head Start" program, utilizing the developmentally appropriate practices they were learning in class to provide high quality early childhood education and care. Students in a marketing/advertising program could assist 
non-profit agencies in promoting their programs and services. Such service-learning experiences would require students to "humanize" the information they were learning in class, and in the end, benefit not only the community, but themselves.

\section{References}

Ash, S.L. (2003). Integrating service-learning into a college-level nutrition course. Journal of Nutrition Education and Behavior, 35, 161-162.

Batchelder, T.H., \& Root, S. (1994). Effects of an undergraduate program to integrate academic learning and service: Cognitive, prosocial cognitive, and identity outcomes. Journal of Adolescence, 17, 341-355.

Boss, J.A. (1995). Teaching ethics through community service. The Journal of Experiential Education, 18(1), 20-24.

Furco, A. (1996). Service-learning: A balanced approach to experiential education. Expanding boundaries: Service and learning. Washington, DC: Corporation for National Service, 2-6.

MacDonald, N.M. (1994). Service learning in undergraduate textiles and clothing. Journal of Family and Consumer Sciences, 84(4), 39-44.

Smith, T.L. (2002). The scholarship of service: Student project aids local food bank. Journal of Family and Consumer Sciences, 94(3), 60-62.

Truesdell, D. (2001). Nutrition education and food for the homeless---University outreach. Journal of Family and Consumer Sciences, 93(1), 37-41.

(C) Copyright of Journal of Youth Development Bridging Research and Practice. Content may not be copied or emailed to multiple sites or posted to a listserv without copyright holder's express written permission. However, users may print, download or email articles for individual use. 